\title{
IMPLEMENTASI LOAD BALANCING BERBASIS CLOUD COMPUTING UNTUK MENDUKUNG INFRASTRUCTURE AS A SERVICE MENGGUNAKAN METODE QUICK SORT
}

\author{
Hero Wintolo ${ }^{1}$, Lalu Suwandi Yusuf ${ }^{2}$ \\ Departemen Informatika \\ Sekolah Tinggi Teknologi Adisutjipto Yogyakarta \\ Jl. Janti, Blok-R, Lanud Adisucipto Yogyakarta \\ ${ }^{1}$ herowintolo@stta.ac.id, ${ }^{2}$ alhamdulillahyusuf@gmail.com
}

\begin{abstract}
Implementation of load balancing in cloud computing applications using quick sort method is a study to determine the access speed of each server. Design a cloud computing application using 4 laptops as application users and 3 laptops or PCs as servers in data storage. In sending data performed by the user application, the data will be distributed to the server that has been selected by the system with a quick sort method that sort the rest of the server capacity and then choose the server with the largest capacity. The stored data is placed in the htdocs file on the server. Based on the tests performed, cloud computing applications can run on at least 2 laptops using the windows version. Testing the server is also done by directly using the command prompt. During testing each server receives ping from the application to determine server performance in using load balancing. Testing without load balancing that sends data 50 times of $10 \mathrm{Mb}$ to one server yields speed $15 \mathrm{~ms}$, with 2 server divided by two in its data delivery that is as much as 25 times $10 \mathrm{Mb}$ then speed $12 \mathrm{~ms}$.
\end{abstract}

Keywords : Load Balancing, Cloud Computing, Quick Sort.

\section{Latar Belakang Masalah}

Perkembangan dunia teknologi informasi saat ini sangatlah pesat, di mana kebutuhan teknologi oleh masyarakat pada umumnya untuk membantu pekerjaan sehari-hari sangat diperlukan. Oleh karenanya bermacam-macam aplikasi atau softwere dibuat guna membantu pekerjaan sehari-hari untuk digunakan oleh masyarakat pada umumnya, sehingga dapat dirasakan manfaatnya dan membantu meringankan beban kerja. Teknologi cloud computing dihadirkan sebagai upaya untuk memungkinkan akses sumber daya dan aplikasi dari mana saja melalui jaringan Internet, sehingga keterbatasan pemanfaatan infrastruktur ICT yang sebelumnya ada dapat diatasi[1]. Jaringan komputer dalam bentuk local area network (LAN) dapat dipergunakan untuk cloud computing dalam bentuk layanan Cloud Infrastructure as a Service (IAAS)[2].

Salah satu layanan Cloud Computing adalah Infrastructure as a Service untuk melayani layanan infrastruktur seperti switch, prosesor, RAM atau memori, dan penyimpanan disk yang cocok untuk kebutuhan pengguna[3]. Dengan infrastruktur seperti ini maka layanan cloud computing dapat dibuat dan diperuntukan pada hal-hal yang berguna bagi masyarakat, salah satunya Sistem Informasi Manajemen (Simpuskesmas). Simpuskesmas Berbasis Cloud Computing merupakan Simpuskesmas yang dulu dalam penerapannya menggunakan client server dirubah ke Simpuskesmas yang di upload di web sehingga puskesmas-puskesmas di Kabupaten Demak dapat mengakses SIMPUS tersebut melalui internet[4].

Dalam kebanyakan kasus, organisasi/ perusahaan yang menggunakan fasilitas komputasi awan pada dasarnya tidak perlu lagi mengetahui dimana sesungguhnya layanan yang diperlukannya dilakukan/diproses, serta tidak perlu tahu lagi dimana data mereka disimpan, karena semuanya sudah diatur oleh vendor komputasi awan. Sementara spesifikasi secara internalnya relatif tidak 
sama untuk masing-masing vendor, komputasi awan dapat kita pikirkan sebagai sumberdaya perangkat keras (komputer, hardisk, dan jaringan komputer) dan perangkat lunak yang bersifat koheren, berukuran raksasa, dan dapat diakses secara meluas. Jadi pada umumnya teknologi cloud computing secara tidak langsung membutuhkan yang sumberdaya-sumberdaya yang ada guna mendukung kelancaran akses oleh pengguna. Maka daripada itu perlu adanya sumberdaya yang bisa mengatur jalannnya lalu lintas data dalam mengakses cloud computing, agar proses akses berjalan dengan lancar dan tanpa hambatan. Salah satu sumberdaya yang digunakan dalam mengatur lalu lintas data yaitu dengan menggunakan metode load balancing. Hasil pengurutan menggunakan metode Quick Sort ini dapat digunakan untuk load balancing dari instruksi yang akan dikirimkan oleh server ke komputer client untuk dilakukan sebuah proses, sehingga keseimbangan kinerja dari aplikasi pemrosesan paralel ini dapat dicapai[5].

\section{Metodologi Penelitian}

Teknologi cloud computing merupakan sebuah model yang memungkinkan untuk ubiquitous (Di manapun dan kapanpun), nyaman digunakan, lebih leluasa akses jaringan ke sumber daya komputasi (contoh: jaringan, server, storage, aplikasi, dan layanan) yang dapat dengan cepat dirilis atau ditambahkan[6]. Gambar 1 menunjukkan konsep dari implementasi load balancing yang akan dibangun. Aplikasi ini merupakan aplikasi berbasis web dan memiliki beberapa server data yang berfungsi sebagai tempat penyimpanan data. Proses awal dimulai dari user melakukan upload sebuah data pada aplikasi. Data-data tersebut akan disimpan pada yang server data dengan cara load balancing ke server yang tersedia. Kemudian, ketika data akan disimpan oleh aplikasi, data tersebut akan tersimpan kepada server yang lebih banyak kapasitas penyimpanannya dengan metode quick sort yaitu server akan diurutkan sesuai dengan kapasistas sisa penyimpanannya masih paling besar. Kemudian, barulah data dapat disimpan.

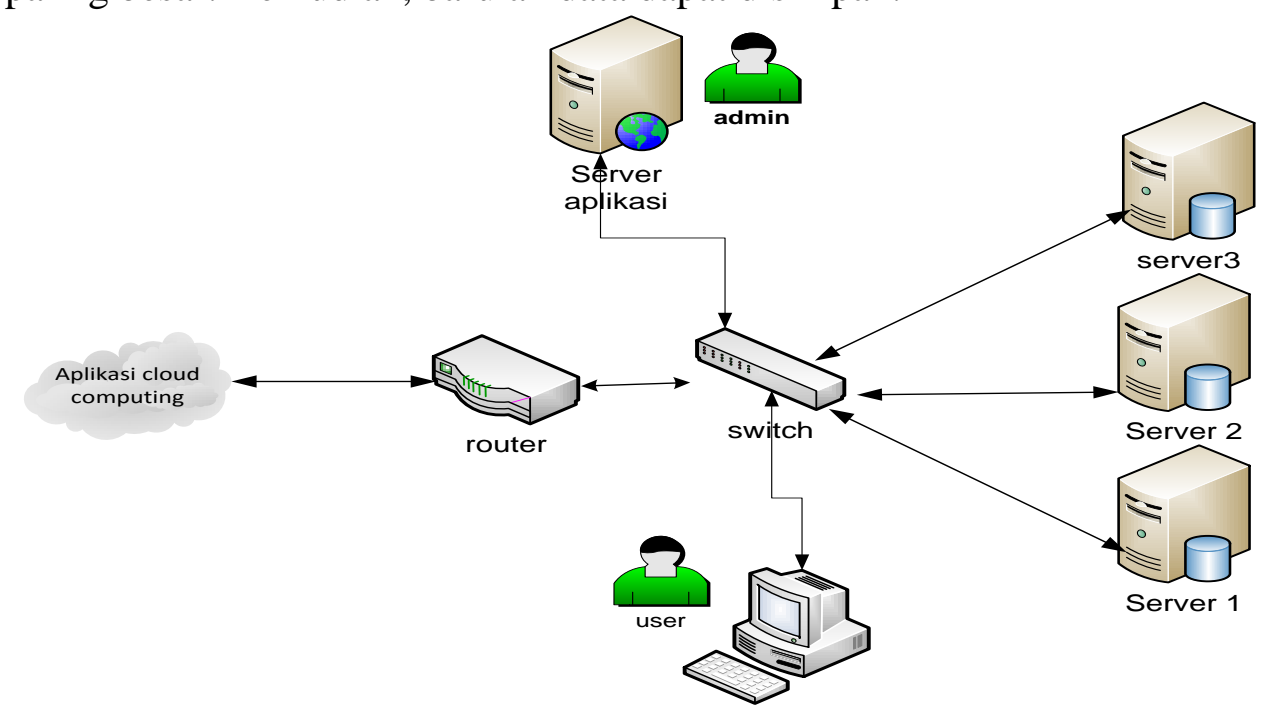

Gambar 1. Gambaran Sistem Aplikasi Cloud Computing

Gambar 2 merupakan diagram konteks aplikasi cloud balancing. Pada Sistem ini hanya terdapat dua entitas yaitu user dan admin. Proses-proses yang dilakukan user terhadap sistem yaitu user dapat melakukan registrasi member dengan memasukan data-data identitas. Agar dapat melakukan upload data, user harus melakukan login member terlebih dahulu dengan memasukan username dan password. Setelah upload data, data tersebut akan ditampilkan ke user. Proses proses yang dilakukan oleh entitas admin adalah melakukan login admin, melihat data member, input data server, hapus member dan hapus data. 


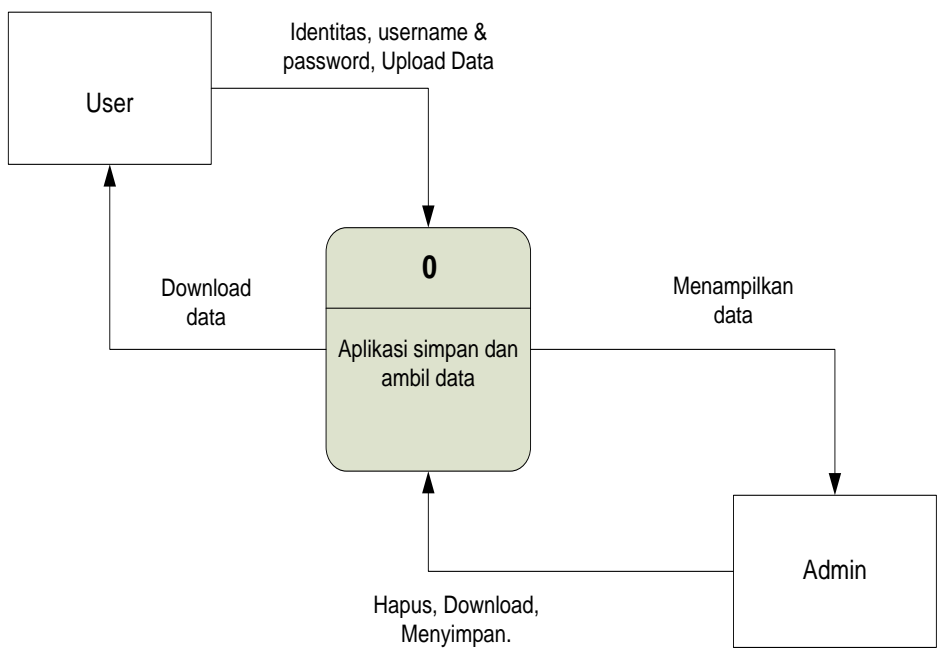

Gambar 2. Diagram Konteks Aplikasi Cloud Computing

\section{Hasil dan Pembahasan}

\subsection{Penjelasan Hasil Rancangan}

Hasil rancangan merupakan hasil penerapan yang telah di konversi menjadi sebuah sistem secara utuh. Pada bagian ini akan mengurai bagaimana hasil rancangan tersebut dalam sebuah keutuhan program. Berikut adalah bagian-bagian dari hasil perancangan yang telah di konversi menjadi sebuah sistem. Pada Gambar 3 terdapat tombol Add server pada sebelah kiri gambar yang fungsinya untuk membuat server baru. Dan tombol logout untuk keluar dari halaman akses.

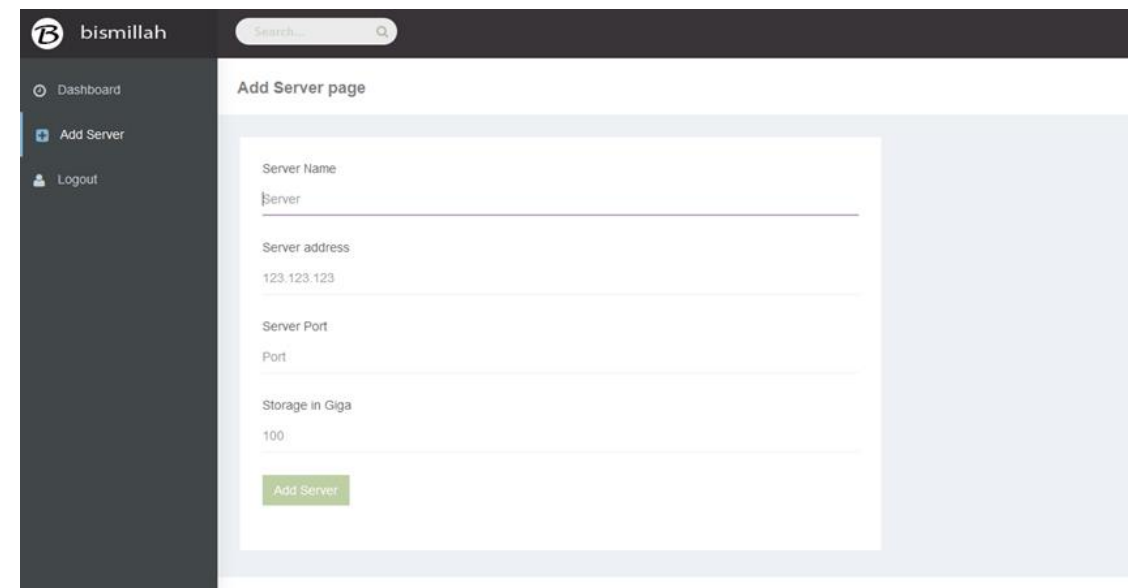

\section{Gambar 3. Form Create Server}

Gambar 4 merupakan halaman untuk server, disini terlihat beberapa server yang telah dibuat dan diisi sebelumnya sehingga menampilkan kapasitas server. Dan pada halaman ini terdapat tombol add server yang berfungsi untuk membuat sebuah server baru sesuai dengan kebutuhan aplikasi. Dalam percobaan ini terdapat 3 buat server yang dimana keseluruhan server diatur oleh admin. Di setiap server terdapat alamat IP yang berbeda-beda. Ketika sebuah data akan disimpan ke server, data yang masih dalam pengiriman akan memilih server yang kapasistas pengimpanannya masih banyak atau masih belum terpakai dengan metode quick sort. 


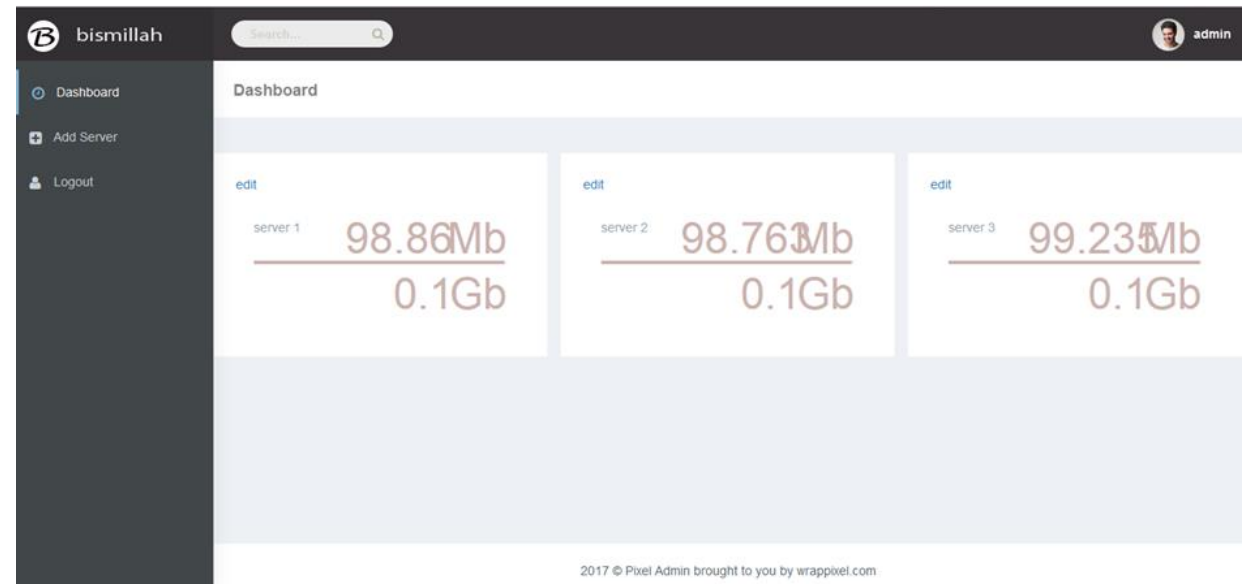

Gambar 4. Form Halaman server

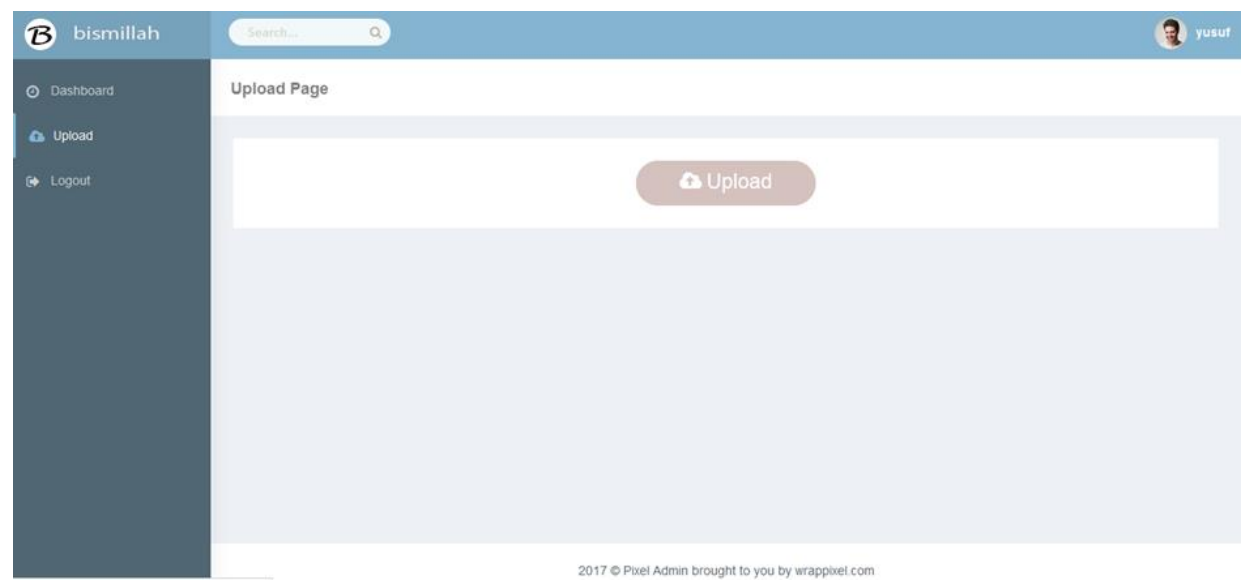

Gambar 5. Form Halaman Upload

Form upload ini berfungsi sebagai saranan untuk membatu user dalam mengupload document. Di form ini tersedia pilihan upload yang kemudian user menekan tombol upload. Kemudian akan menampilkan form untuk menamai data dan memilih data untuk transaksi upload.

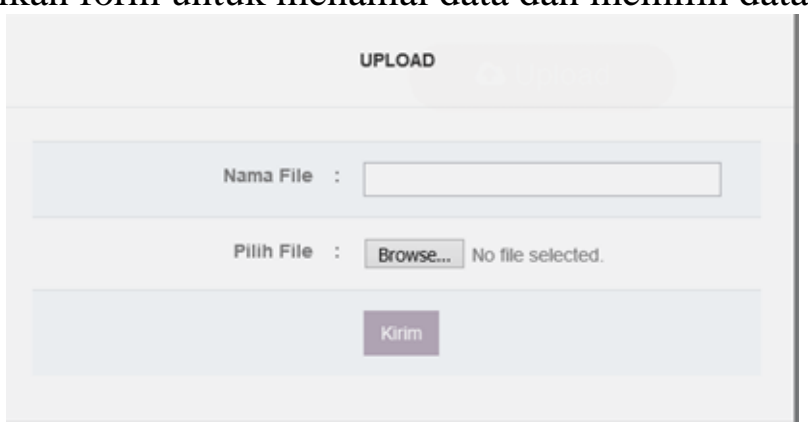

\section{Gambar 6. Form Transaksi Upload}

Proses transaksi Upload dilakukan pada halaman transaksi seperti terlihat pada Gambar 6, user diharuskan mengisi nama data dan file data yang akan disimpan ke server. Setelah user mengisi data, klik tombol kirim untuk menyimpan data yang telah dipilihnya. File yang telah diunggah akan terlihat seperti pada gambar 7. Pada halaman daftar ini, user bisa melihat data yang sudah diuploadnya. User bisa mengakses data miliknya sendiri dengan mengklik tombol download dan bisa juga untuk menghapus data miliknya sendiri dan user bisa mengetahui bahwa status server tempat data user berada dalam keadaan online atau offline. Meskipun dalam keadaan offline user masih bisa mengakses data yang telah disimpan sebelumnya. 


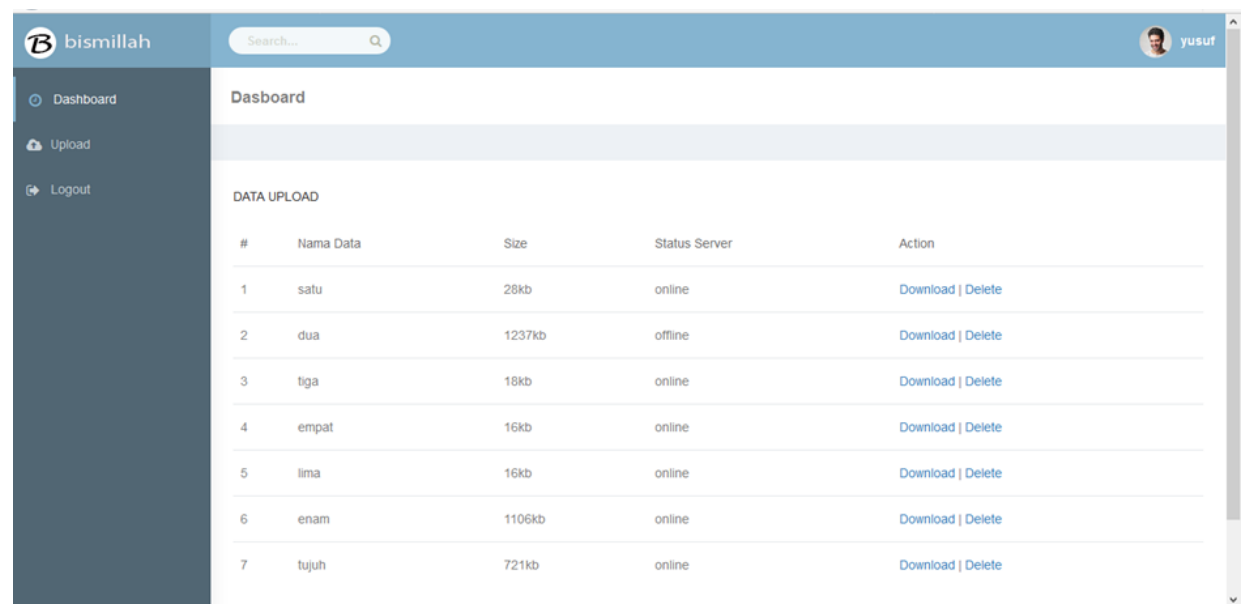

Gambar 7. Form Halaman Daftar File Upload

\subsection{Pengujian}

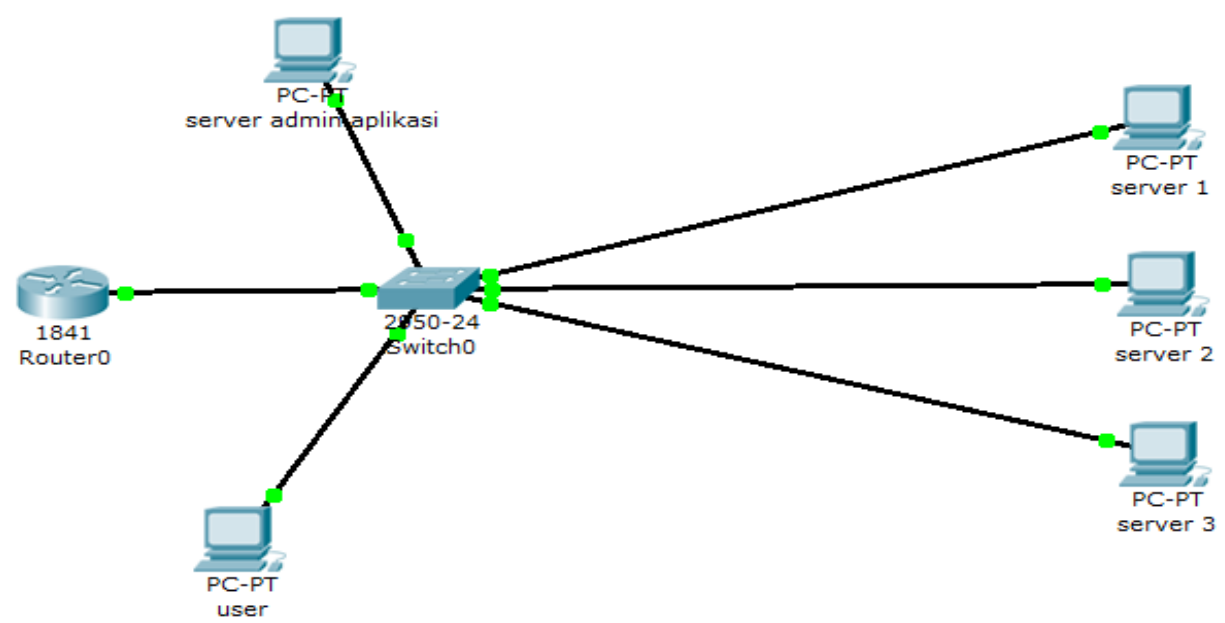

Gambar 8. Skema Pengujian

Pengujian yang pertama kali merupakan pengunjian fungsi untuk menilai kinerja hasil rancangan sudah sesuai atau belum dengan tujuan penelitian. Selama uji fungsi menggunakan simulasi, terlebih dahulu membuat alamat $I P$ yang sifatnya statis guna memudahkan dalam pengujian. Dalam pengalamatan IP dapat di lihat pada Tabel 1yaitu daftar IPAddress.

Tabel 1. Daftar IP Address

\begin{tabular}{|l|c|c|c|}
\hline \multicolumn{1}{|c|}{ Nama Perangkat } & IP & Subnet & Server \\
\hline Router & 192.168 .100 .1 & 255.255 .255 .0 & - \\
\hline Server Aplikasi & 192.168 .100 .2 & 255.255 .255 .0 & 192.168 .100 .1 \\
\hline Server Data 1 & 192.168 .100 .3 & 255.255 .255 .0 & 192.168 .100 .1 \\
\hline Server Data 2 & 192.168 .100 .4 & 255.255 .255 .0 & 192.168 .100 .1 \\
\hline Server Data 3 & 192.168 .100 .5 & 255.255 .255 .0 & 192.168 .100 .1 \\
\hline Komputer User & 192.168 .100 .5 & 255.255 .255 .0 & 192.168 .100 .1 \\
\hline
\end{tabular}


Setiap server mempunyai alamat IP yang berbeda-beda yaitu server 1 IP Addressnya 192.168.10.3, server 2 IP Addressnya 192.168.10.4, server 3 IP Addressnya 192.168.10.5. sedangkan komputer user 192.168.10.6 dan server aplikasi IP Addressnya 192.168.10.2. Dalam uji coba mendapatkan hasil proses bahwa ketika user mengakses setiap server, waktu yang dibutuhkan berbeda-beda pada saat menggunakan alat simulasi softwere packet tracer.

Tabel 2. Hasil Proses Pengujian Menggunakan Packet Tracer

\begin{tabular}{|c|c|c|c|}
\hline Server & Waktu Min & Waktu Max & Rata-rata \\
\hline Server 1/192.168.10.3 & $46 \mathrm{~ms}$ & $63 \mathrm{~ms}$ & $57 \mathrm{~ms}$ \\
\hline Server 2/192.168.10.4 & $31 \mathrm{~ms}$ & $63 \mathrm{~ms}$ & $58 \mathrm{~ms}$ \\
\hline Server 3/192.168.10.5 & $31 \mathrm{~ms}$ & $63 \mathrm{~ms}$ & $59 \mathrm{~ms}$ \\
\hline
\end{tabular}

Pada Tabel 2, hasil proses pengujian menggunakan packet tracer, waktu rata-rata akses antara server satu dengan yang lainnya berbeda-beda. Hal ini mempengaruhi kecepatan dalam pengiriman sebuah paket data.

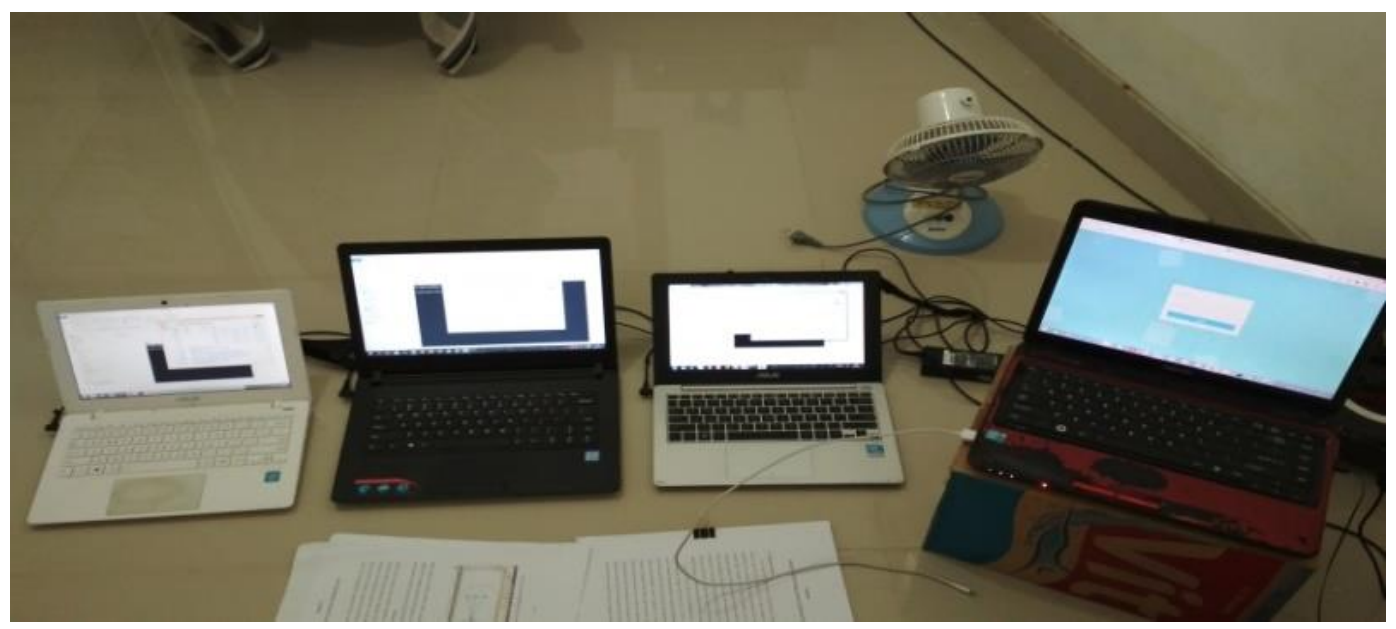

Gambar 9. Alat Uji Aplikasi dan Server

Pengujian selanjutnya dilakukan dengan mengimplementasikannya pada peralatan computer dan jaringan computer secara langsung. Dalam pengujian alat terdapat 4 buah komputer, 1 diantaranya digunakan sebagai admin/user selebihnya sebagai server. Dalam pengujian akan dilakukan dua cara untuk mengetahui perbedaan dari load balancing melalui cmd online dan data yang dikirim dalam pengujian, sebesar 10.000 byte atau $10 \mathrm{Mb}$.

Pengujian yang pertama menggunakan satu server (tanpa load balancing) yaitu pengujian yang dilakukan oleh user guna melakukan pengiriman paket data ke salah 1 server dari 3 server yang ada sebanyak 50 kali. Hasilnya, kecepatan minimumnya 7 ms rata-rata yang didapatkan 15 ms. 


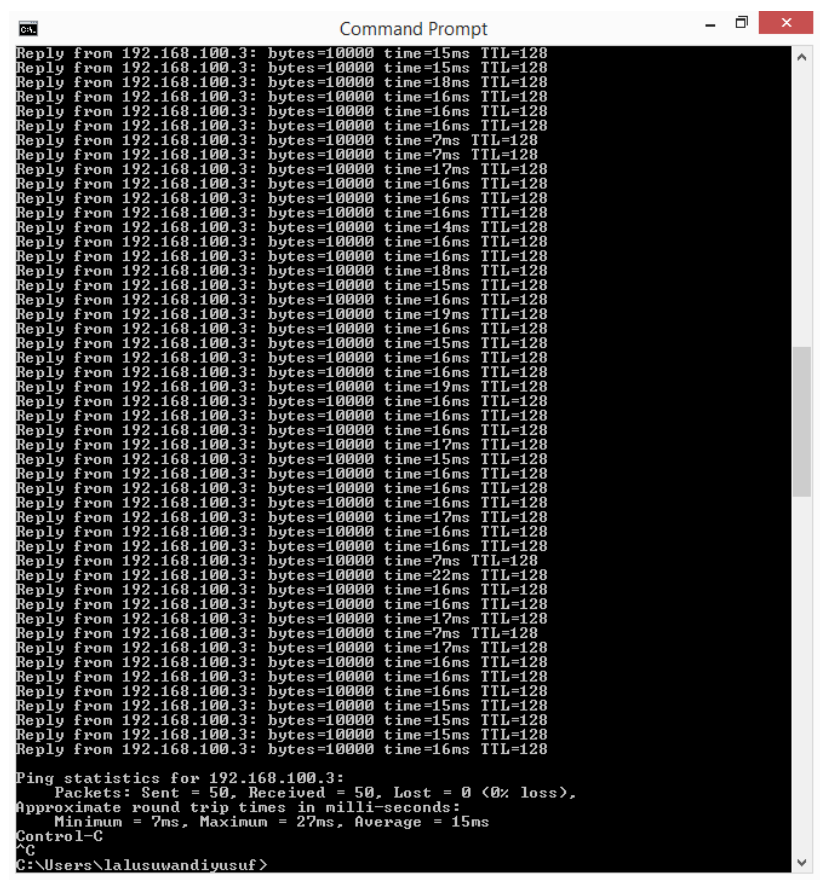

Gambar 10. Hasil Pengujian dengan 1 Server

Pengujian yang kedua dengan melibatkan 2 server (load balancing) yaitu untuk membuktikan bahwa penggunaan load balancing dapat dapat lebih mengefisiensikan waktu pengiriman data. Pada proses dan hasil pengujian dengan 2 server bagian satu merupakan hasil perbandingan dari pengiriman packet data ke server, yang mana hasil setiap kecepatan yang didapatkan rata-rata 13 $m s$ akan menjadi perbandingan untuk pengujian yang menggunkan 2 server.

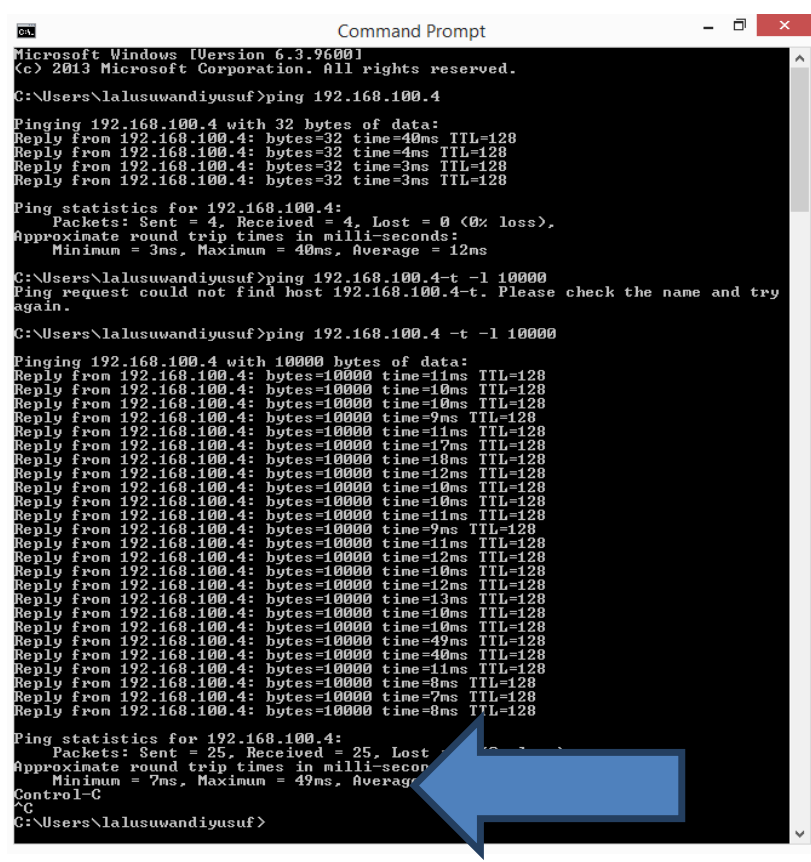

Gambar 11. Proses dan Hasil Pengujian dengan 2 Server Bagian Satu. 


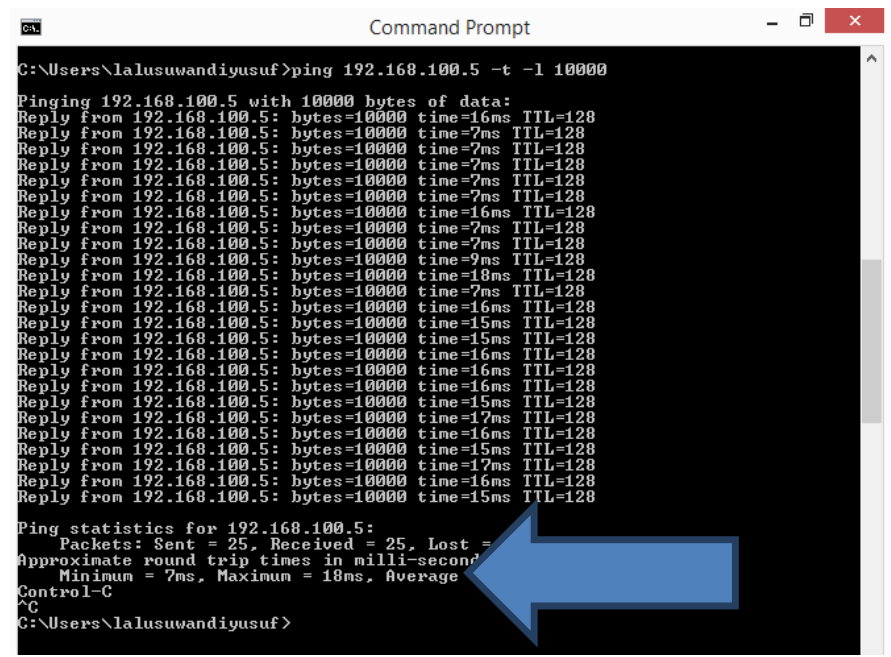

Gambar 12. Proses dan Hasil Pengujian dengan 2 Server Bagian Dua

Selanjutnya proses dan hasil pengujian dengan 2 server bagian dua juga mendapatkan kecepatan dengan rata-rata $12 \mathrm{~ms}$.

Tabel 3. Hasil proses pengujian menggunakan online

\begin{tabular}{|c|c|c|c|c|}
\hline Nama/Alamat IP & $\begin{array}{c}\text { Waktu } \\
\text { Min }\end{array}$ & $\begin{array}{c}\text { Waktu } \\
\text { Max }\end{array}$ & Rata-rata & $\begin{array}{c}\text { Load } \\
\text { balancing }\end{array}$ \\
\hline Server 1 /192.168.100.3 & $7 \mathrm{~ms}$ & $27 \mathrm{~ms}$ & $15 \mathrm{~ms}$ & Tidak \\
\hline Server 2 /192.168.100.4 & $7 \mathrm{~ms}$ & $49 \mathrm{~ms}$ & $13 \mathrm{~ms}$ & Pakai \\
\hline Server 3 /192.168.100.5 & $7 \mathrm{~ms}$ & $18 \mathrm{~ms}$ & $12 \mathrm{~ms}$ & Pakai \\
\hline
\end{tabular}

Dalam pengujian tersebut, dapat disimpulkan bahwa penggunaan dua server atau lebih (load balancing) mengakibatkan proses yang dihasilkan lebih ringan dalam memproses suatu pengiriman paket data dari pada tidak menggunakan load balancing. Seperti pada gambar 4.9, uji coba dilakukan dengan memberikan 10.000 byte atau $10 \mathrm{Mb}$ selama 50 kali akses kepada server 1 , kemudian 25 kali akses pada server 2 dan 3 guna mengetahui kinerja dari setiap pada server.

Kemudian melakukan dan memperlihatkan uji alat dari beberapa server yang sudah dikirimkan data dari aplikasi. Dalam berbagai percobaan yang dilakukan, data yang dikirimkan oleh user dapat berbeda tempat penyimpanannya dikarenakan aplikasi akan membaca kapasitas server yang tersedia dan kemudian kapasitas server yang paling besar akan didahulukan dalam pengisian data yang dikirimkan oleh user.

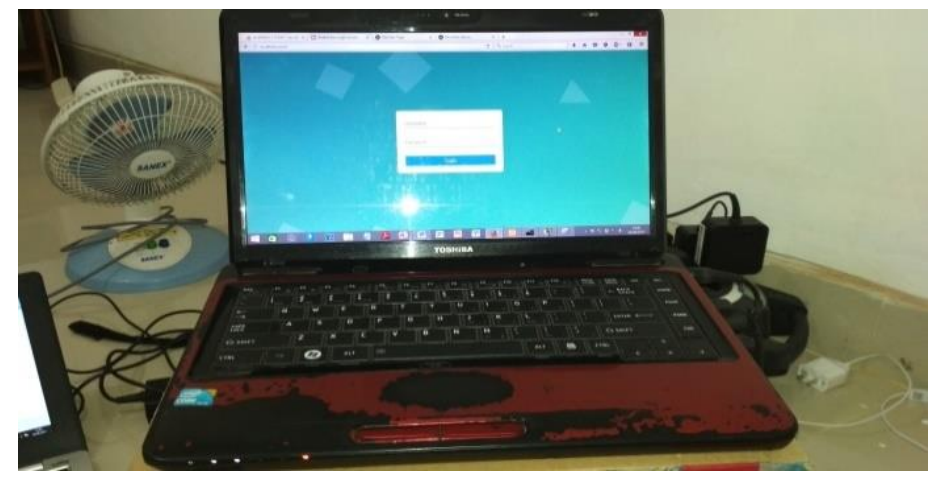

Gambar 13. Alat Uji Satu Sebagai Aplikasi 
Pada alat uji satu berfungsi sebagai user sekaligus sebagai admin dalam aplikasi. Selain itu juga berfungsi sebagai server aplikasi yang membackup file setiap kali ada transaksi pengiriman data ke server. sehingga bilamana ada salah satu dari 3 server dalam keaadaan offline, data yang ada di dalamnya masih bisa diakses.

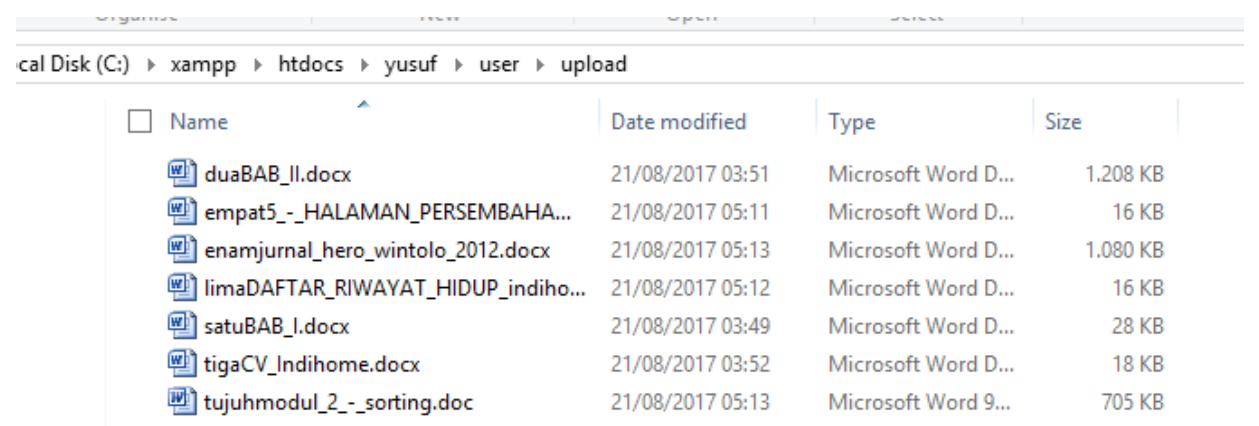

\section{Gambar 14. Bukti Backup Data Pada Server Aplikasi}

Gambar bukti backup data pada server aplikasi menunjukkan data user juga berada pada server aplikasi. Untuk mengantisipasi user yang akan mengaskes datanya jika sewaktu-waktu server ada yang offline.

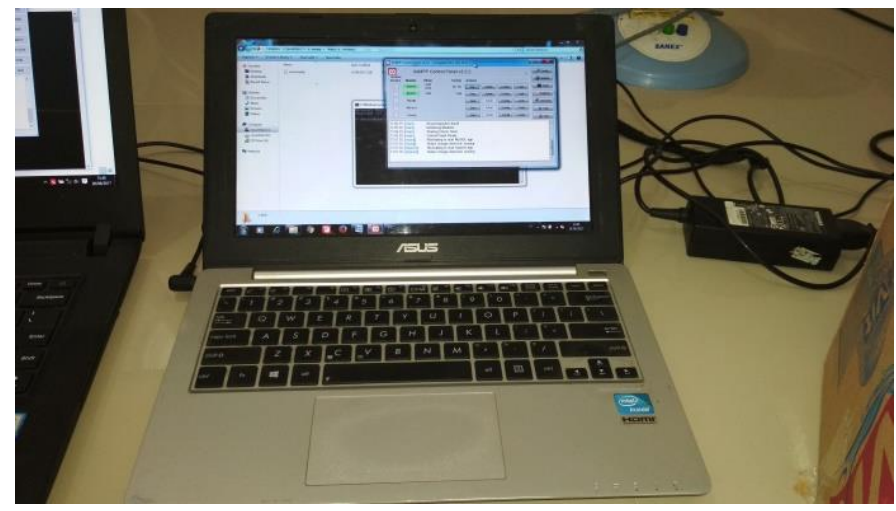

Gambar 15. Alat Uji Dua Sebagai Server 1

Pada alat uji dua merupakan salah satu server yang menjadi server 1 dalam menyimpan data user dan telah menyisipkan alamat IP 192.168.100.3. Hasil dari penyimpanan file user ke server 1 menunjukan bahwa keberhasilan transaksi yang dilakukan user dalam menyimpan file data pada server 1 .

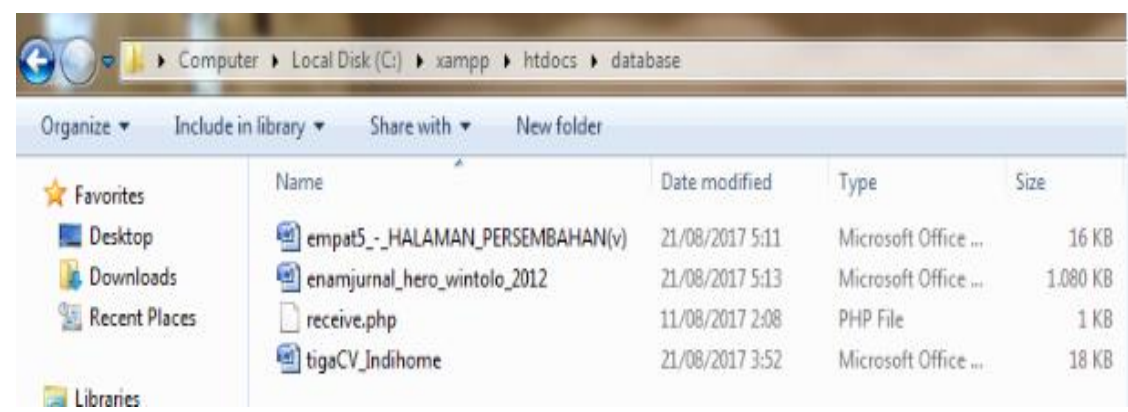

Gambar 16. Bukti Terkirimnya File Data Pada Laptop 1 Sebagai Server 1 


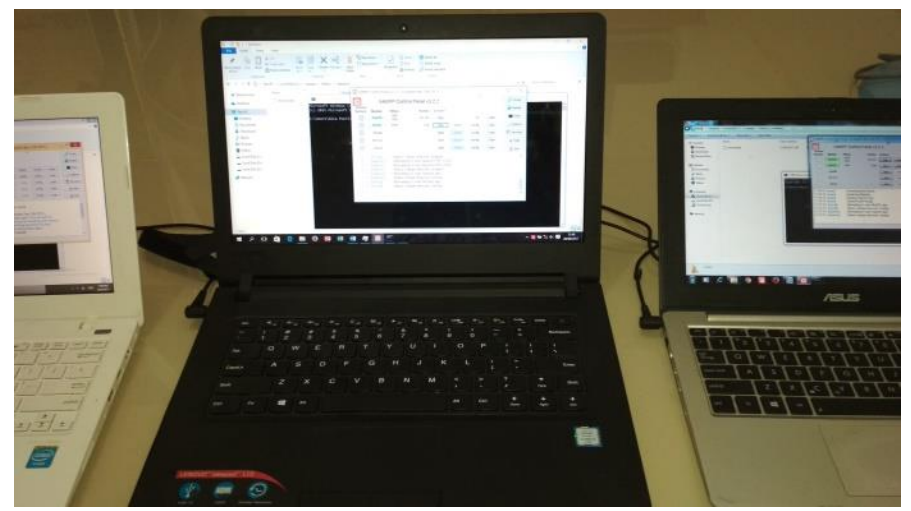

Gambar 17. Alat Uji Tiga Sebagai Server 2

Pada alat uji tiga yang berfungsi sebagai server 2 sudah di setting memiliki alamat IP 192.168.100.4 dan kapasitas untuk server. Pada server alat uji tiga, data yang dikirimkan oleh user dari aplikasi ke server bahwa data tersebut sudah masuk dan bertempat pada folder penyimpanan yang ada di server 2.

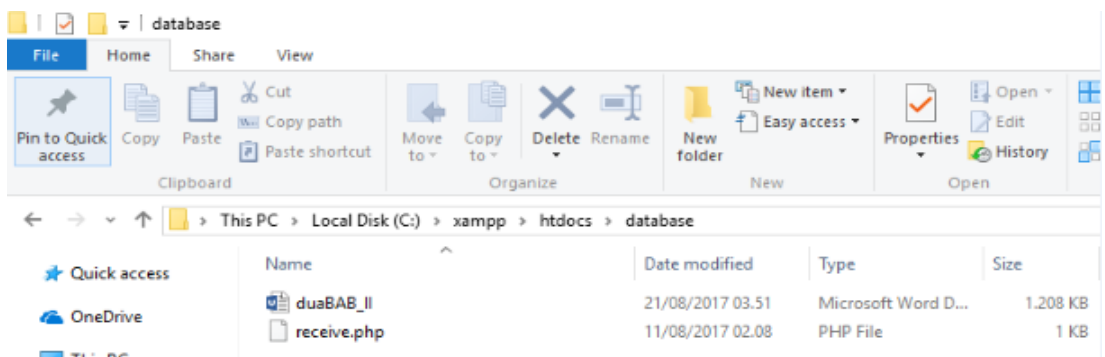

Gambar 18. Bukti Terkirimnya File Data Pada Laptop 2 Sebagai Server 2

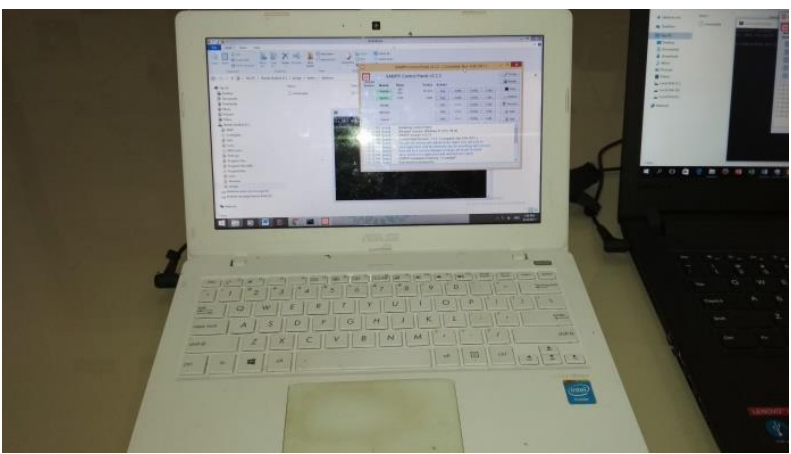

Gambar 19. Alat Uji Empat Sebagai Server 3

Selanjutnya laptop terakhir yang digunakan sebagai alat uji yang ke empat, fungsi utamanya juga tidak jauh berbeda dengan server 1 dan server 2 yaitu sebagai server 3 . Pada server 3 sudah ada alamat IP 192.168.100.5 yang sudah di setting sebelumnya. Kemudian dari hasil beberapa percobaan yang dilakukan, data user disimpan pada server 3 . Artinya ketika user mengirimkan file data, aplikasi akan mengarahkan data user ke tempat server yang kapasitas ruang penyimpanannya masih tersisa banyak. Meskipun dalam pengiriman data cukup banyak, akan tetapi yang terhitung pada aplikasi adalah kapasitas file data. 


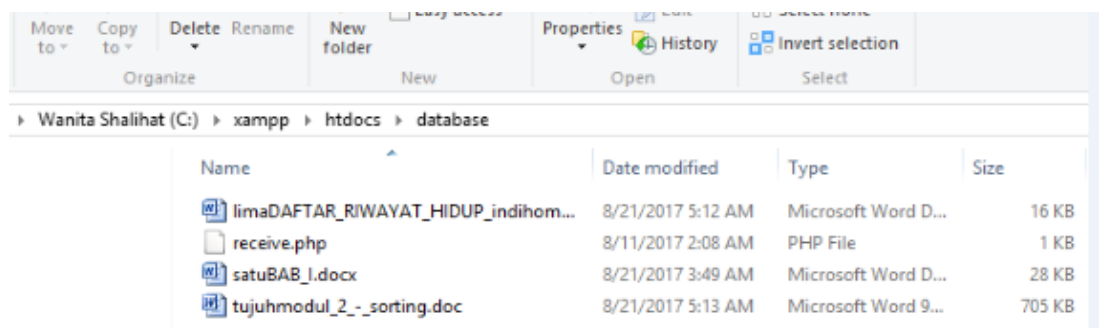

Gambar 20. Bukti Terkirimnya File Data Pada Laptop 3 Sebagai Server 3

\section{Kesimpulan}

Kesimpulan yang diperoleh dari hasil uji fungsi dan uji alat aplikasi cloud computing ini adalah sebagai berikut :

1. Pengiriman data sebanyak $50 \mathrm{kali}$ dan data yang dikirim sebesar 10.000 byte atau $10 \mathrm{Mb}$ kepada 1 server yang menghasilkan kecepatan $15 \mathrm{~ms}$, dengan 2 server dibagi dua dalam pengiriman datanya yatu sebanyak 25 kali dan sebesar 10.000 maka kecepatan $12 \mathrm{~ms}$.

2. Penerapan metode quick sort mengurutkan sisa kapasitas yang paling besar sehingga bisa dipastikan data tersebut berada pada server yang kapasitasnya paling besar.

3. Data yang tersimpan tetap bisa diakses oleh user. Data tersebut tersimpan pada server aplikasi dan juga disalah satu server yang sudah ada. Sehingga data yang disimpan bisa diakses dalam keadaan off.

\section{Daftar Pustaka}

[1] Ashari, A. and Setiawan, H., 2011. Cloud Computing: Solusi ICT?. Jurnal Sistem Informasi, $3(2)$.

[2] Wintolo, H., Kusumaningrum, A. and Kusuma, H.W., 2017. Use of Automation Codecs Streaming Video Applications Based on Cloud Computing. Telkomnika, 15(3).

[3] Sulistyowati, L., Sulistyo, W. and Bayu, T.I., 2012. Implementasi Cloud Computing Sebagai Infrastructure as a Service untuk Penyediaan Web Server.

[4] Wibisono, S. and Munawaroh, S., 2012. Sistem Informasi Manajemen Puskesmas (Simpuskesmas) berbasis Cloud Computing. Dinamik-Jurnal Teknologi Informasi, 17(2).

[5] Wintolo, H., Penerapan Quick Sort pada Pemrosesan Parallel Berbasis Personal Komputer (PC) dalam Local Area Network (LAN) Guna Mendukung Load Balancing.

[6] Mell, P. and Grance, T., 2011. The NIST definition of cloud computing. 